\title{
Oxalate and tannins assessment in Atriplex halimus L. and A. nummularia L.
}

\author{
M. MW. ABU-ZANAT, F. M. AL-HASSANAT, M. ALAWI AND G. B. RUYLE
}

Authors are Associate Professor of Range Management, and former Graduate Student, Dept. of Animal Production; Professor of Organic Chemistry, Dept. of Chemistry, Jordan University, Amman, Jordan; and Professor of Range Management, School of Renewable Natural Resources, The University of Arizona, Tucson, Ariz.

\section{Abstract}

The study was conducted at 3 locations in the arid region of Jordan to assess the seasonal changes of oxalate and tannins in Atriplex halimus L. and A. nummularia $\mathrm{L}$. plants commonly used for revegetation of degraded rangelands. During spring and fall seasons, 20 shrubs of each species were selected randomly at each location, 20 similar twigs per shrub were clipped and analyzed for oxalate and tannins. Atriplex halimus contained higher levels of oxalate $(7.00 \%)$ compared with $A$. nummularia plants $(6.20 \%)$ $(P<0.001)$. Oxalate levels averaged 8.29 and $4.92 \%$ in spring and fall season, respectively. Plants of $A$. halimus accumulated more oxalate in spring than those of $A$. nummularia. Clipping had no effect on oxalate concentration. The seedlings of $A$. nummularia contained more oxalate than old plants whereas old shrubs of $A$. halimus contained more oxalate than the young seedlings. The browse of $A$. halimus contained more condensed and hydrolyzable tannins $(1.05 \%$ and $0.67 \%, P<0.0001)$ than $A$. nummularia $(0.80 \%$ and $0.39 \%, P<0.0001)$, respectively. Clipping had no effect on the levels of tannic phenols, condensed and hydrolyzable tannins. Young plants of the 2 species had higher levels of condensed tannins compared to older plants. However, seedlings of $\boldsymbol{A}$. nummularia contained significantly higher levels of condensed tannins compared to $A$. halimus seedlings $(1.57 \%$ and $1.47 \%$, respectively). Atriplex halimus synthesized more oxalate, tannic phenols, condensed and hydrolyzable tannins than $A$. nummularia. These secondary metabolites may explain the low palatability of Atriplex halimus compared to A. nummularia.

Key Words: Atriplex halimus, Atriplex nummularia, tannins, oxalate, clipping, arid region

Rangelands in Jordan cover $90 \%$ of the total surface area of the country. Serious declines in productivity have occurred over extensive areas of these lands. This decline takes the form of depletion of high value fodder species and their replacement by plants that are less productive, less palatable, and less nutritious than the original plants they replaced (Abu-Zanat 1995). Artificial revegetation may be a tool for rehabilitation of these degraded rangelands. Because of drought and scarcity of precipi-

Research was funded by the Government of Jordan and the European Commission as Project No: SEM/03/628/021 (Jordan Arid Zone Productivity Project: JAZPP). Authors wish to thank Dr. M. Tabbaa for assistance in statistical analyses.

Manuscript accepted 25 Sept. 02.

\section{Resumen}

El estudio se condujo en $\mathbf{t} 3$ localidades de la región árida de Jordania para evaluar los cambios estacionales del los oxalatos y taninos en Atriplex halimus L. y A. nummularia L., plantas comúnmente utilizadas para revegetar áreas de pastizal degradadas. Durante primavera y otoño en cada localidad se seleccionaron aleatoriamente 20 arbustos de cada especie y se cortaron 20 ramas similares por arbusto y fueron analizadas para determinar el contenido de oxalatos y taninos. El Atriplex halimus presentó más altos niveles de oxalatos (7.00\%) que el A. nummularia $(6.20 \%)(P<\mathbf{0 . 0 0 1})$. Los niveles de oxalatos promediaron 8.29 y $4.92 \%$ en primavera y otoño respectivamente. En primavera, las plantas de $\boldsymbol{A}$. halimus acumularon mas oxalatos que las de $\boldsymbol{A}$. nummularia. El corte no tuvo efecto en la concentración de oxalatos. Las plántulas de $A$. nummularia contenían mas oxalatos que las plantas viejas mientras que los arbustos viejos de $A$. halimus presentaron a mas oxalatos que las plántulas. El forraje ramoneable de $A$. halimus contenía mas taninos condensados e hidrolizables $(1.05 \%$ y $0.67 \%, \mathrm{P}<0.0001)$ que $A$. nummularia $(0.80 \%$ y $0.39 \%, P<0.0001)$. El corte no tuvo efecto en los niveles de fenoles tánicos y taninos condensados e hidrolizables. Las plantas jóvenes de las dos especies tuvieron niveles mas altos de taninos condensados que las plantas viejas. Sin embargo, las plántulas de $A$. nummularia contenían niveles significativamente mas altos de taninos condensados que las plántulas de A. halimus $(1.57 \%$ y $1.47 \%$, respectivamente). Atriplex halimus sintetizó mas oxalatos, fenoles tanicos, taninos condensados e hidrolizables que $A$. nummularia. Estos metabolitos secundarios pueden explicar la baja gustocidad del Atriplex halimus comparado con el $A$. nummularia.

tation, fodder shrubs are preferred to herbaceous species for rangeland revegetation. In Jordan, the common fodder shrubs that are used for revegetation are Atriplex halimus L. and A. nummularia L. Atriplex halimus is native to Jordan and represents 60 to $70 \%$ of saltbush plantations in the Middle East region (LeHouerou 1994) whereas, Atriplex nummularia is an introduced species from Australia. However, they contain secondary chemical compounds, which may restrict grazing by herbivores. The type, level and activity of these chemical compounds depend on the age of plants as well as growing conditions (Cheeke 1995).

Atriplex species accumulate oxalates (James 1977, Libert and Franceschi 1987) up to 4-16\% DM (Barry and Blaney 1987). Both soil salinity and moisture can alter the level of oxalate in the plant. Plants growing in saline soil need oxalates for osmo-regulation of $\mathrm{Na}, \mathrm{K}$ and $\mathrm{Cl}$ ions (Cymbaluk et al. 1986). Under high 
soil moisture, Atriplex halimus plants were reported to accumulate higher levels of oxalate in leaves and twigs (Ellern et al. 1974). Plants containing $10 \%$ oxalate or more are considered toxic and should not be grazed (James 1977).

Tannins, on the other hand, are a chemically diverse group of water-soluble phenols, which bind proteins to form insoluble complexes (Hagerman et al. 1992). The level of tannins in the plant is not constant. Factors within the plant and the external environment influence the variability of tannin levels. Within a given species the proportion of tannins may change with plant maturity and/or climatic stress (Singleton 1981). Factors that may increase tannin level in plants are low soil fertility, drought and high temperature. Tannins inhibit cellulolytic and protolytic enzymes and decrease the production of volatile fatty acids, microbial DNA and RNA in the rumen. Feeding tannins to ruminant animals in large amounts have produced negative effects on the animal, inducing low feed palatability, inhibited digestion, and may cause systematic animal poisoning (Singleton 1981, Kumar and Singh 1984).

The objectives of this study were to: 1) assess the seasonal levels of oxalate and tannins in Atriplex halimus and A. nummularia in the arid region of Jordan, and 2) compare the effect of clipping versus no clipping on the level of tannins and oxalate in the browse of the 2 species.

\section{Materials and Methods}

\section{Experimental Sites}

The study was conducted at 3 locations: Khanasry $\left(36^{\circ} 03^{\prime} 05^{\prime \prime} \mathrm{E}, 32^{\circ} 26^{\prime} 4^{\prime \prime} \mathrm{N}\right)$, Muwaqqar ( $\left.36^{\circ} 13^{\prime} 30^{\prime \prime} \mathrm{E}, 31^{\circ} 46^{\prime} 40^{\prime \prime} \mathrm{N}\right)$ and Khalideyah ( $36^{\circ} 17^{\prime} 42^{\prime \prime}$ E, 32 $32^{\circ} 10^{\prime} 36^{\prime \prime}$ $\mathrm{N})$ research stations. These locations are classified in Jordan as arid lands with annual rainfall of $100-200 \mathrm{~mm}$. Rainfall is basically irregular, sporadic, and poorly distributed. Maximum and minimum temperatures ranged between $11-35^{\circ} \mathrm{C}$ and 2 $17^{\circ} \mathrm{C}$, respectively with a relative humidity of $57 \%$, which ranged between $86 \%$ in winter and $40 \%$ in summer. The soil is mainly silt-clay with a $\mathrm{pH}$ between 6.7-8.1.

\section{Plant Material}

In 1985, seeds of Atriplex halimus were collected from Jordan and seeds of Atriplex nummularia were introduced from Australia. All plant collections were propagated at the Khalideyah Nursery,
Mafraq Governorate, which is the only source of all saltbush plantations existing at the experimental sites and range reserves in Jordan. In October 1996, seedlings of $A$. halimus and A. nummularia (9 months old) were transplanted in contour furrows at the 3 experimental sites. Old shrubs (5-10 years) of both species existed at all the sites.

\section{Sampling}

Browse from seedlings and old plants of A. halimus and A. nummularia was collected during May (spring season) and November (fall season) in 1997. At each location, 20 shrubs of each species and age class were selected randomly and tagged with plastic wires at the main stem. Twenty identical twigs $(1 \mathrm{~cm}$ in diameter, $10-15 \mathrm{~cm}$ long) from each shrub were selected randomly from all sides of the shrub and clipped. The samples from each shrub were placed into plastic bags for weight determination and chemical analysis. In November 1997, regrowth of twigs previously clipped in May were re-clipped to determine the effect of clipping (a simulation of grazing) on the content of tannins and oxalate.

\section{Chemical Analysis}

Since the equipment for freeze drying is not available, the samples were dried using an air-circulating oven at $25^{\circ} \mathrm{C}$ for 48 hours according to Makker et al. (1988) and dry weights were recorded. The low drying temperature was selected to prevent the degradation of tannins by excessive heating (Makker et al. 1988). Waterman and Mole (1994) preferred that the drying temperature should be higher than $40^{\circ} \mathrm{C}$ to avoid oxidation by the still active enzymes and lower than $60^{\circ} \mathrm{C}$ to avoid heat damage and polymerization. The partially dried samples were ground to $0.2-\mathrm{mm}$ mesh size and stored in plastic bags into a refrigerator at $3 \pm 1^{\circ} \mathrm{C}$ for later chemical analysis. The dry matter of browse was determined by placing the residues of samples in an oven and dried at $100 \pm 5^{\circ}$ $\mathrm{C}$ for 48 hours.

Oxalate content was determined according to the procedure of the AOAC (1990). A sample weighing $1.5 \mathrm{~g}$ was treated with HCL (6 M), boiled for 30 minutes and the solution was filtered into a $100 \mathrm{ml}$ volumetric flask. The solution was treated with $5 \mathrm{ml}$ of tungstophosphoric acid reagent, after filtration the $\mathrm{pH}$ of the solution was adjusted to 4-4.5 using $\mathrm{NH}_{4} \mathrm{OH}$ and acetate buffer. Test tubes were centrifuged at $1700 \mathrm{rpm}$ for 15 minutes and the oxalate crystals were redissolved by $5 \mathrm{ml}$ of $\mathrm{H}_{2} \mathrm{SO}_{4}(10 \%)$ and titrated with $\mathrm{KMnO}_{4}(0.01 \mathrm{M})$. All types of oxalates existing in the plant material were converted to oxalic acid, precipitated and titrated with $\mathrm{KMnO}_{4}$.

Tannins were determined according to Makker and Goodchild (1996). Tannins were extracted from the sample $(100 \mathrm{mg})$ using $10 \mathrm{ml}$ of $70 \%$ ultra-pure acetone, immersed into an ice-cold sonicator and exposed to ultra-sonic for 15 minutes, transferred into a test tube and centrifuged at $3000 \mathrm{rpm}$ for 20 minutes. The supernatant was separated and stored at $3^{\circ} \mathrm{C}$. The dye Folin-Ciocalteau was added to 0.5 $\mathrm{ml}$ of the extract and absorbtion of the dye-phenolics complex was measured at $725 \mathrm{~nm}$ wavelength. The amount of total phenols as tannic acid equivalent was determined from a calibration curve (10$60 \mathrm{mg}$ tannic acid/ liter). Tannins were precipitated using polyvinil pyrrolidones and $1.0 \mathrm{ml}$ of the tannins extract was centrifuged at $3000 \mathrm{rpm}$ for 15 minutes and the supernatant containing only simple non-tannic phenols was collected. The dye Folin-Ciocalteau was added to $0.5 \mathrm{ml}$ of the supernatant and absorbance of the dyephenolics complex was measured at 725 $\mathrm{nm}$ wavelength. Tannic phenols were calculated as the difference between total phenols and non-tannic phenols. Condensed tannins were determined by mixing the tannic extract with butanolHCL reagent and ferric ammonium sulfate in a screw cap test tube. The test tube was heated in a water bath $\left(97-100^{\circ} \mathrm{C}\right)$ for 60 minutes, cooled and absorbance was measured at $550 \mathrm{~nm}$ wavelength. Hydrolyzable tannins were calculated as the difference between tannic phenols and condensed tannins. Duplicates of each sample were analyzed for the confirmation of results. All results were expressed on a dry matter basis.

The least square analysis of variance was performed on data using the SAS General Linear Models (GLM) procedure for a randomized complete block design (SAS 1988). The first analysis compared experimental sites, shrub species, season and the appropriate interactions. The second analysis compared shrub species, age (seedlings versus old plants) and the appropriate interactions. The third analysis compared the effect of previous clipping on these components in secondary growth tissue and included experimental sites, shrub species, time of clipping and the appropriate interactions. Variables considered in the statistical analysis were oxalates, total phenols, non-tannic phenols, tannic phenols, condensed and 
hydrolyzable tannins. A protected LSD test was used to compare means.

\section{Results and Discussion}

\section{Oxalate}

Shrub Species

Oxalate content differed between Atriplex halimus and A. nummularia (Table 1). Regardless of location or season, A. halimus contained significantly ( $\mathrm{P}$ $<0.001)$ higher levels of oxalate $(7.01 \%)$ compared with $A$. nummularia $(6.20 \%)$. The oxalate content in the 2 shrub species ranged between $4.17 \%$ and $10.67 \%$ and averaged $6.5 \%$. The oxalate values reported in this study are within the range of values (4-1\%) reported in various studies reviewed by Barry and Blaney (1987). A significant $(\mathrm{P}<0.0001)$ location $\mathrm{x}$ shrub species interaction in oxalate content resulted from high levels of oxalates in $A$. halimus (7.84\%) and low levels of oxalates in $A$. nummularia $(5.97 \%)$ at the Khalideyah site. The soils of this site are characterized by high salt content.

\section{Season}

Seasonal variations greatly affected the level of oxalate in A. halimus and A. nummularia. The 2 saltbush species contained much higher levels of oxalate during spring $(8.96 \%$ and $7.62 \%)$ compared to fall season $(5.06 \%$ and $4.78 \%$ ) for $\mathrm{A}$. halimus and $A$. nummularia, respectively. Moisture stress during the fall season may have reduced oxalate levels, or mature tissue synthesized less oxalate (Ellern et al. 1974). During the fall season, there was no significant difference in oxalate content between the two-saltbush species, whereas, in the spring, plants of A. halimus accumulated more oxalate than $A$. nummularia (Table 1). There was a significant ( $\mathrm{P}$ $<0.0001)$ location $\mathrm{x}$ season interaction in oxalates content due to variations in soil salinity among the experimental sites.

Table 1. Seasonal changes in oxalate levels ${ }^{1}$ in Atriplex halimus and Atriplex nummularia plants growing at 3 locations in the arid region of Jordan.

\begin{tabular}{|c|c|c|c|c|}
\hline \multirow[t]{2}{*}{ Location } & \multicolumn{2}{|c|}{ Spring } & \multicolumn{2}{|c|}{ Eall } \\
\hline & A. halimus & A. nummularia & A. halimus & A. nummularia \\
\hline Khanasry & $8.53 \pm 0.20 \mathrm{~b}^{2}$ & $7.80 \pm 0.18 c$ & $5.35 \pm 0.18 d$ & $5.37 \pm 0.18 d$ \\
\hline Muwaqqar & $7.67 \pm 0.20 \mathrm{c}$ & $7.29 \pm 0.18 c$ & $4.83 \pm 0.18 \mathrm{de}$ & $4.80 \pm 0.16 \mathrm{e}$ \\
\hline Khalideyah & $10.67 \pm 0.18 a$ & $7.77 \pm 0.20 \mathrm{c}$ & $5.00 \pm 0.16 \mathrm{de}$ & $4.17 \pm 0.18 f$ \\
\hline Species mean ${ }^{3}$ & $8.96 \mathrm{a}$ & $7.62 b$ & $5.06 \mathrm{c}$ & $4.78 \mathrm{c}$ \\
\hline Season mean ${ }^{3}$ & & & & \\
\hline
\end{tabular}

${ }^{1}$ Least square means as \% on dry matter basis \pm standar error.

${ }^{2}$ Means within columns and rows followed by the same letter are not significantly different at the 0.05 level of probability.

${ }^{3}$ Means within a row followed by the same letter are not significantly different at the 0.05 level of probability. 0.05 level of probability.

\section{Clipping}

Clipping had no effect on the oxalate concentrations of saltbush plants, $4.99 \%$ in unclipped twigs versus $4.80 \%$ in regrowth. Clipping was confined to some twigs and not for the whole shrub. This lenient clipping was not severe enough to induce substantial differences in oxalate synthesis of saltbush plants.

Table 2. Seasonal changes in levels ${ }^{1}$ of total phenolic compounds, non-tannic phenols, tannic phenols, condensed tannins and hydrolyzable tannins in Atriplex halimus and Atriplex nummularia plants growing at 3 locations in the arid region of Jordan.

\begin{tabular}{|c|c|c|c|c|}
\hline \multirow[t]{2}{*}{ Location } & \multicolumn{2}{|c|}{ Spring } & \multicolumn{2}{|c|}{ Eall } \\
\hline & A. halimus & A. nummularia & A. halimus & A. nummularia \\
\hline \multicolumn{5}{|l|}{ Total phenols } \\
\hline Khanasry & $1.98 \mathrm{ab}^{2}$ & $1.22 \mathrm{c}$ & $1.10 \mathrm{c}$ & $1.09 \mathrm{c}$ \\
\hline Muwaqqar & $2.15 \mathrm{a}$ & $1.69 b$ & $1.48 \mathrm{bc}$ & $2.04 \mathrm{a}$ \\
\hline Khalideyah & $2.28 \mathrm{a}$ & $1.43 \mathrm{bc}$ & $2.28 \mathrm{a}$ & $0.71 d$ \\
\hline Location mean ${ }^{3}$ & $2.14 \mathrm{a}$ & $1.45 \mathrm{~b}$ & $1.62 \mathrm{~b}$ & $1.28 \mathrm{bc}$ \\
\hline Season mean ${ }^{3}$ & \multicolumn{2}{|c|}{$1.79 a$} & \multicolumn{2}{|c|}{$1.45 b$} \\
\hline \multicolumn{5}{|l|}{ Non-tannic phenols } \\
\hline Khanasry & $0.14 \mathrm{c}$ & $0.28 \mathrm{a}$ & $0.13 c$ & $0.05 \mathrm{~d}$ \\
\hline Muwaqqar & $0.12 \mathrm{c}$ & $0.21 b$ & $0.07 \mathrm{~cd}$ & $0.14 \mathrm{c}$ \\
\hline Khalideyah & $0.23 b$ & $0.25 b$ & $0.22 b$ & $0.09 \mathrm{c}$ \\
\hline Location mean $^{3}$ & $0.16 \mathrm{~b}$ & $0.25 \mathrm{a}$ & $0.14 \mathrm{c}$ & $0.09 \mathrm{~d}$ \\
\hline Season mean ${ }^{3}$ & \multicolumn{2}{|c|}{$0.21 \mathrm{a}$} & \multicolumn{2}{|c|}{$0.12 b$} \\
\hline \multicolumn{5}{|l|}{ Tannic phenols } \\
\hline Khanasry & $1.84 \mathrm{a}$ & $0.95 \mathrm{c}$ & $0.97 \mathrm{c}$ & $1.03 \mathrm{c}$ \\
\hline Muwaqqar & $2.02 \mathrm{a}$ & $1.48 \mathrm{~b}$ & $1.40 \mathrm{~b}$ & $1.91 \mathrm{a}$ \\
\hline Khalideyah & $2.03 \mathrm{a}$ & $1.18 b c$ & $2.05 \mathrm{a}$ & $0.61 \mathrm{~d}$ \\
\hline Location mean ${ }^{3}$ & $1.97 \mathrm{a}$ & $1.20 \mathrm{c}$ & $1.47 \mathrm{~b}$ & $1.18 \mathrm{c}$ \\
\hline Season mean ${ }^{3}$ & \multicolumn{2}{|c|}{$1.58 \mathrm{a}$} & \multicolumn{2}{|c|}{$1.33 \mathrm{~b}$} \\
\hline \multicolumn{5}{|l|}{ Condensed tannins } \\
\hline Khanasry & $1.57 \mathrm{a}$ & $0.74 \mathrm{e}$ & $0.63 \mathrm{e}$ & $0.68 \mathrm{e}$ \\
\hline Muwaqqar & $1.08 \mathrm{c}$ & $1.15 \mathrm{c}$ & $0.85 \mathrm{~d}$ & $0.72 \mathrm{e}$ \\
\hline Khalideyah & $1.25 \mathrm{~b}$ & $1.05 \mathrm{c}$ & $0.89 \mathrm{~d}$ & $0.44 \mathrm{f}$ \\
\hline Location mean ${ }^{3}$ & $1.30 \mathrm{a}$ & $0.98 b$ & $0.79 \mathrm{c}$ & $0.61 d$ \\
\hline Season mean ${ }^{3}$ & \multicolumn{2}{|c|}{$1.14 \mathrm{a}$} & \multicolumn{2}{|c|}{$0.70 \mathrm{~b}$} \\
\hline \multicolumn{5}{|l|}{ Hydrolyzable tannins } \\
\hline Khanasry & $0.27 \mathrm{~cd}$ & $0.21 \mathrm{~d}$ & $0.33 \mathrm{~cd}$ & $0.36 \mathrm{~cd}$ \\
\hline Muwaqqar & $0.95 \mathrm{ab}$ & $0.32 \mathrm{~cd}$ & $0.54 \mathrm{c}$ & $1.18 \mathrm{a}$ \\
\hline Khalideyah & $0.78 b c$ & $0.13 \mathrm{~d}$ & $1.16 \mathrm{a}$ & $0.17 \mathrm{~d}$ \\
\hline Location mean ${ }^{3}$ & $0.67 a$ & $0.22 b$ & $0.68 \mathrm{a}$ & $0.57 \mathrm{a}$ \\
\hline Season mean ${ }^{3}$ & \multicolumn{2}{|c|}{$0.44 b$} & \multicolumn{2}{|c|}{$0.62 a$} \\
\hline
\end{tabular}

${ }^{1}$ Least square means as \% on dry matter basis. Standard errors of least square means are $0.11,0.01,0.11,0.03$ and 0.11 for total phenols, non-tannic phenols, tannic phenols, condensed tannins and hydrolyzable tannins, respectively.

${ }^{2}$ Means within columns and rows for each parameter followed by the same letter are not significantly different at the

Shrub Age

A significant interaction $(\mathrm{P}<0.001)$ existed between shrub species and age. Seedlings of A. nummularia contained more oxalate than old plants $(9.65 \%$ and $7.63 \%, \mathrm{P}>0.0001)$, whereas old shrubs of A. halimus $(10.69 \%)$ contained more oxalate than the young seedlings $(8.8 \%)(\mathrm{P}$ $<0.0001$ ). Young seedlings of $A$. nummularia contained more oxalate $(9.65 \%)$ than the seedlings of $A$. halimus $(8.83 \%)$ $(\mathrm{P}<0.005)$. During early stages of growth, there is a rapid rise in oxalate content followed by a decline in oxalate level as the plant matures (Davis 1981, Hodgkinson 1977).

\section{Tannins \\ Shrub Species}

Atriplex halimus contained more total phenols (1.88\% vs $1.36 \%)$, tannic phenols ( $1.72 \%$ vs $1.19 \%)$, condensed tannins $(1.0 \%$ vs $0.80 \%)$ and hydrolyzable tannins $(0.6 \%$ vs $0.3 \%$ ) than $A$. nummularia ( $\mathrm{P}<$ 0.0001 ) (Table 2). Levels of tannic phe- 
nols in the 2 saltbush species varied between $0.61 \%$ to $2.05 \%$ and averaged $1.46 \%$. These values are much higher than those reported by Davis (1981) for various saltbush species in different countries $(0.32 \%$ to $0.9 \%)$. Variation in levels of tannins among saltbush plants and even within the same species could be attributed to differences in soil and climatic conditions of the sites (Barry and Blaney 1987). Difference in plant ability to synthesize tannins is well-documented (Mangan 1988, Davis 1981). These higher levels of tannins in the tissues of $A$. halimus may explain its low palatability compared to the browse of $A$. nummularia.

The type of tannins is more important than the quantity of tanninc phenols regarding the nutrition of animals. The hydrolyzable tannins have adverse effects on health and nutrition of animals compared to condensed tannins which mainly reduce the palatability of feeds. Plants of A. halimus contained more condensed and hydrolyzable tannins ( 1.05 and $0.67 \%$ ) than those of $A$. nummularia $(0.89$ and $0.39 \%$ ). The ratio of hydrolyzable to condensed tannins was 0.64 in A. halimus compared to 0.49 in $A$. nummularia plants. A significant $(\mathrm{P}<0.0001)$ shrub species by location interaction in condensed tannins resulted from high content of condensed tannins in A. halimus $(1.07 \%)$ and low levels in A. nummularia $(0.75 \%)$ at the Khalideyah site. A similar pattern of shrub species by location interaction $(\mathrm{P}<$ 0.0001 ) was also noted for hydrolyzable tannins which peaked to $0.97 \%$ in A. halimus and dropped to the lowest levels $(0.15 \%)$ in $A$. nummularia plants.

\section{Season}

In spring, saltbush plants contained higher levels of tannic phenols and condensed tannins (1.58\% and $1.14 \%$ ) compared to fall levels $(1.33 \%$ and $0.70 \%$, respectively) $(\mathrm{P}<0.001)$. These results did not agree with the findings of Davis (1981), who observed no significant differences in the levels of tannin phenols in A. halimus plants compared to A. nuтmularia in spring and fall seasons.

The temporal variation in tannic phenols resulted from the variation of environmental factors prevailing in the 2 seasons. Saltbush plants synthesized more tannins in the spring season, apparently because of more favorable growth factors prevailing in spring compared to fall season, or due to the higher metabolic rate of the younger tissues. Twigs in the fall season had a low leaf: stem ratio compared to more leafiness in the spring. Since most of tannins exists in the leaves (Van Soest 1994, Barahona et al. 1997), it was expected that spring growth would contain higher levels of total and condensed tannins than the fall growth and regrowth.

\section{Clipping}

Clipping of saltbush plants had no effect on the level of total $(P>0.3)$ or condensed tannins $(\mathrm{P}>0.8)$. This means that the severity of defoliation of saltbush shrubs was not enough to stimulate or hinder the ability of plants to synthesize tannic compounds. The lenient and confined clipping of selected twigs did not enhance the biosynthesis of total tannins as a defensive mechanism against herbivores.

\section{Shrub Age}

Significant difference $(\mathrm{P}<0.001)$ in total tannins existed between young and old plants of $A$. nummularia $(2.03 \%$ and $1.25 \%$, respectively) but not in A. halimus (Table 3). However, condensed tannins were higher in various plants of both species. Young plants tended to produce more condensed tannins than old plants because they are more leafy. Young plants of $A$. halimus contained similar levels of total tannins as young seedlings of $A$. nummularia. However, seedlings of $A$. nummularia contained significantly $(\mathrm{P}<$ 0.01 ) higher levels of condensed tannins compared to A. halimus seedlings $(1.57 \%$ and $1.47 \%$, respectively).

\section{Potential Toxicity Problems}

Allison et al. (1977) reported that sheep ingesting between $39-51 \mathrm{~g}$ of calcium oxalate per day are likely to develop acute signs of toxicity. Theoretically, if sheep consume a diet solely of Atriplex plants grown in Jordan, they will ingest about $132 \mathrm{~g}$ of calcium oxalate $(6.6 \%$ calcium

Table 3. Levels ${ }^{1}$ of total phenolic compounds, non-tannic phenols, tannic phenols, condensed tannins and hydrolyzable tannins in Atriplex halimus and Atriplex nummularia seedlings compared to old plants growing in the arid region of Jordan.

\begin{tabular}{lcccc}
\hline \hline & \multicolumn{2}{c}{ Seedlings } & \multicolumn{2}{c}{ Old Plants } \\
\cline { 2 - 4 } \cline { 2 - 4 } & A. halimus & A. nummularia & A. halimus & A. nummularia \\
\hline & $-1.03 \mathrm{~b}^{2}$ & $2.41 \mathrm{a}$ & $2.25 \mathrm{ab}$ & $1.50 \mathrm{c}$ \\
Notal phenols & $0.15 \mathrm{c}$ & $0.37 \mathrm{a}$ & $0.23 \mathrm{~b}$ & $0.25 \mathrm{~b}$ \\
Non-tannic phenols & $1.88 \mathrm{a}$ & $2.03 \mathrm{a}$ & $2.01 \mathrm{a}$ & $1.25 \mathrm{~b}$ \\
Connic phenols & $1.47 \mathrm{~b}$ & $1.57 \mathrm{a}$ & $1.24 \mathrm{c}$ & $1.08 \mathrm{~d}$ \\
Hydronsed tannins & $0.41 \mathrm{~b}$ & $0.47 \mathrm{~b}$ & $0.78 \mathrm{a}$ & $0.17 \mathrm{c}$ \\
\hline
\end{tabular}

${ }^{1}$ Least square means as \% on dry matter basis. Standar errors of least square means are $0.196,0.089,0.007,0.087$ 0.027 and 0.071 for total phenols, non-tannic phenols, tannic phenols, condensed tannins and hydrolyzable tannins, respectively.

${ }^{2}$ Means within a row followed by the same letter are not significantly different at the 0.05 level of probability. oxalate $=66 \mathrm{~g}$ per $\mathrm{kg} \mathrm{DM} \times 2 \mathrm{~kg}$ per day per sheep $=132 \mathrm{~g}$ ) and are likely to develop acute signs of toxicity. Practically, the potential of toxicoses due to oxalate levels present in the browse of saltbush is low because of selectivity and adaptation of ruminants to high levels of oxalate. James and Butcher (1972) reported that sheep can consume a diet containing $6 \%$ oxalate However, these animals developed diarrhea and refused to consume such a diet again. Oxalate poisoning occurs at the point where oxalate is absorbed faster than populations of oxalate degrading microbes in the rumen. Adapted animals can consume $30 \%$ more oxalate than unadapted ones (James 1977). In general, oxalate poisoning is a complex issue. Factors such as chemical form of oxalate, animal maturity, adaptation of animals to saltbush, the comwater for animals could influence the susceptibility of animals to oxalate poisoning.

Several studies dealt with the problem of toxicity due to high levels of tannins ( $>6$ $\%$ ) in animals diet (Kumar and Singh . However, animals refused to con(Donnelly and Anthony 1969). levels of tannins (less than 4\%) in forages can have beneficial responses in ruminants due to the increased amount of bypass proteins, resulting in higher growth rates (Nunez-Hernandez et al. 1991). The levels of tannins in the saltbushes grown in Jordan are not expected to have adverse effects on sheep grazing these plantations associated with abundance of herbaceous plants.

\section{Conclusion}

In summary, our study showed that the 2 saltbush species contained higher levels of without showing any toxicity signs. be degraded by ruminal microflora. position of the diet, and the availability of 
oxalate, tannic phenols and condensed tannins during spring compared to fall season. Atriplex halimus is characterized by high levels of oxalate, tannic phenols, condensed and hydrolyzable tannins than $A$. nummularia which explanis its low palatability. Spring clipping of saltbush plants had no significant effect on oxalate or tannins concentration of subsequent clippings taken in fall. The levels of secondary metabolites found in our experiments indicate that if sheep were to consume a diet solely of Atriplex, they would be likely to develop acute toxicity symptoms. Future work should examine the different chemical forms of oxalates and tannins in the browse of saltbushes in response to different defoliation intensities and under different environmental conditions.

\section{Literature Cited}

Abu-Zanat, M. 1995. Establishment and production of fodder shrubs in Jordan. Regional Planning Workshop on Fodder Shrubs. Tunis, Tunisia, 3-6 July.

Allison, M.J., E.T. Littlekid, and L.F. James. 1977. Changes in ruminal oxalate degradation associated with adaptation to oxalate ingestion. J. Anim. Sci. 45:1173-1179.

Association of Official Analytical Chemists (AOAC). 1990. Official Methods of Analysis. $15^{\text {th }}$ Edition. AOAC, Washington, D.C.

Barahona, R., C.E. Lascano, R. Cochran, J. Morrill, and E.C. Titgemeyere. 1997. Intake, digestion, and nitrogen utilization by sheep fed tropical legumes with contrasting tannin concentration and astringency. $J$. Anim. Sci. 75:1633-1640.
Barry, T.N. and Blaney, B.J. 1987. Secondary compounds of forages, p 90-120. In: J.B Hacker and J.H Ternouth, (eds.) Nutrition of Herbivores. Academic Press, New York, N.Y. USA.

Cheeke, P.R. 1995. Endogenous toxins and myco-toxins in forage grasses and their effect on livestock. J. Anim. Sci. 73:909-918.

Cymbaluk, N.F., J.D. Miller, and D.A. Christensen. 1986. Oxalate concentration in feeds and its metabolism by ponies. Can. J. of Anim. Sci.. 66:1107-1116.

Davis, A.M. 1981. Oxalate, tannins, crude fiber and crude protein composition of young plants of some Atriplex sp. J. Range. Manage. 34:329-331.

Donnelly, E.D. and W.B. Anthony. 1969. Relation of tannin, dry matter digestibility and crude protein of Sericea lespedeza. Crop Sci. 9:361-362.

Ellern, S.J., Y.B. Samish, and D. Lachover. 1974. Salt and oxalic acid content of leaves in the saltbush Atriplex halimus in the Northern Negev. J. Range. Manage. 27:267-271.

Hagerman, A.E., C.T. Robbins, Y. Weerasuriya, T.C. Wilson, and C. Mcarther. 1992. Tannin chemistry in relation to digestion. J. Range. Manage. 45:57-62.

Hodgkinson, A., 1977. Oxalic acid in biology and medicine. Academic Press, New York, N.Y. USA.

James, L.F. 1977. Oxalate poisoning in livestock. p. 135-145. In: R.F Keeler, K.R. Van Kampen and L.F. James (eds.) Effects of Poisonous Plants on Livestock. Academic Press, New York, N.Y. USA.

James, L.F. and J. Butcher. 1972. Halogeton poisoning of sheep: effect of high level oxalate intake. J. Anim Sci. 35:1233-1238.

Kumar, R. and M. Singh. 1984. Tannins: Their adverse role in ruminant nutrition. J. Agr. Fd. Chem. 32:447-459.
LeHourou, H. N. 1994. Forage halophytes and salt-tolerant fodder crops in the Mediterranean Basin. p. 123-137. In: V.R. Squires and A.T. Ayoub (eds.) Halophytes as a Resource for Livestock and for Rehabilitation of Degraded Lands. Kluwer Academic Publishers, The Netherlands.

Libert, B. and V.R. Franceschi. 1987. Oxalate in crop plants. J. Agr. Fd. Chem. 35:926-938.

Makker, H.P.S. and A.V. Goodchild. 1996. Quantification of tannins: A laboratory manual. International Center For Agricultural Research in Dry Lands. Aleppo, Syria.

Makker, H.P.S., B. Singh, and R.K. Dawra. 1988. Effect of tannin rich leaves of oak (Quercus incana) on various microbial enzymes activities of the bovine rumen. Br. J. Nut. 60:287-296.

Mangan, J.L. 1988. Nutritional effect of tannins in animal feeds. Nut. Res. Rev. 15:209-213.

Numez-Hernandez, G., J.D. Wallace, J.L. Holechek, M.L. Galyean, and M. Cardenas. Condensed tannins and nutrient utilization by lambs and goats fed low-quality diets. J. Anim. Sci. 69:1167-1177.

SAS Institute, Inc. 1988. SAS/STAT User's Guide, Version 6, Fourth Edition, Vol. 2, SAS Inst., Cary, N.C., USA.

Singleton, V.L. 1981. Naturally occurring food toxin: Phenolic substances of plant origin common in foods. Adv. Food Res.. 27:149-242.

Van Soest, P.J. 1994. Nutritional ecology of the ruminants, $2^{\text {nd }}$ Ed. Comstock Cornell Univ. Press, Cornell, Penn. USA.

Waterman, P. G. and S. Mole. 1994. Analysis of phenolic plant metabolites. Blackwell Sci. Publ., Oxford, UK. 